\title{
FROM SOLDIER-POET TO VETERAN MEMOIRIST: SIEGFRIED SASSOON, THE COMPLETE MEMOIRS OF GEORGE SHERSTON, AND THE LIMITS OF LIFE-WRITING IN PROSE
}

\author{
Sean A. McPhail ${ }^{{ }^{*}}$ \\ ${ }^{1}$ University of Toronto, Toronto, Ontario, Canada
}

\begin{abstract}
The Complete Memoirs of George Sherston is a key text supporting Siegfried Sassoon's reputation as Britain's pre-eminent Great War-writer. Critics have nevertheless reached no consensus as to whether these lightly fictionalised "memoirs" represent true accounts of Sherston's/ Sassoon's war or fictional constructions. They have also yet to account for the differences between the Memoirs and Sassoon's war-poetry, and between Sherston's stated commemorative goals and his complete account. This article dissects the Memoirs' adaptation of Sassoon's front-line poetics of commemoration: it reads their new application of this poetics via his compositional difficulties, his dependence upon his own wartime writings, and life-writing's uneasy relationship to truth. As I show, Sherston has more in common with his author than Sassoon intended, but differences remain; still, his memoirs have as much right to that appellation as any other text in the language.
\end{abstract}

Keywords: Commemoration; First World War; Life-Writing; Memoir; Siegfried Sassoon

\footnotetext{
Recently defended his dissertation, Fraternity on the Front Lines: Siegfried Sassoon, Fictive Kinship, and the First World War, with the Department of English at the University of Toronto. He also holds a Bachelor of Arts (Honours) in English and German and a Master of Arts in English from Queen's University in Kingston, Canada. His research focusses primarily upon the relationship between kinship and commemoration in the works of the Great War writer Siegfried Sassoon. Other scholarly interests include British and Irish Modernisms, twentieth- and twenty-first century German literature, and the short story. Email: sean.mcphail@mail.utoronto. ca. ORCID: https://orcid.org/0000-0003-3238-4320.
} 
Siegfried Sassoon has long occupied a central position within the conventional cast of protest-poets with whom scholarship and the British public associate the literature of the First World War. While Sassoon's overrepresentation in the war canon has faced increasing scrutiny in recent decades-most recently from critics like Sally Minogue and Andrew Palmer (2018) and Santanu Das (2018) -it is interesting to note that his reputation as anti-war writer first attained its apex during the interwar period. Interesting because the 1920s, following the 1919 publication of his collected War Poems (1988), brought with them a dramatic reduction in Sassoon's composition of poetry explicitly concerning war. More interesting still because the late 1920s and the 1930s saw Sassoon alter his approach to commemorative war-writing by abandoning short, realist war-poetry in favour of longform prose-memoir. Scholarship on Sassoon has yet to fully account for the significance of this shift to the global narrative told across his war-oeuvre.

If he is still primarily read as the realist soldier-poet who exploded onto England's literary scene in 1917, Sassoon's reputation also depends upon his Complete Memoirs of George Sherston (1980, collected 1937), which comprises three popular volumes: Memoirs of a Fox-hunting Man (FHM 1980 [1928]), Memoirs of an Infantry Officer (IO 1980 [1930]), and Sherston's Progress (SP 1980 [1936]). As their titles suggest, these memoirs present longform accounts of "Sherston's" experiences up to and including his service in the Great War. Despite their popularity, however, critics have long struggled to place the Memoirs generically: while most contemporary scholars agree with Paul Edwards' reading of Sherston as presenting a lightly altered account of true events $(2008,23)$, Edwards is himself reacting to Paul Fussell's 1975 classification of the trilogy as fiction (2000). Bernard Bergonzi meanwhile laments that Sherston's memoirs "fall rather unhappily between the separate forms of strict autobiography and the autobiographical novel" $(1996,150)$. Finally, Jean Moorcroft Wilson reads them as romans à clef, including a key to their pseudonyms with the supplemental material of her biography on post-war Sassoon (2005, 175, 495-97).

Criticism on the Complete Memoirs has also yet to account for just how much Sherston's war narrative differs from that contained within Sassoon's front-line poetry. To see this, one need only look at their adaptation Sassoon's commemorative poetics-the mode for memorialising his fallen comrades that he had developed in his war-poetry and modified to suit his post-war needs as veteran memoirist. Where Sassoon's verse had developed rapidly, its character changing fundamentally between his first deployment in late 1915 and war's end, his literary progression after 1918 was slower and subtler. If the final narrative of the Sherston Memoirs is closer in character to that of his late-war verse than that verse is to his poetry of the early-war, it nevertheless differs in certain key respects that-given the text's and its author's centrality within the Great War canon-deserve more robust scholarly discussion. Such a discussion will also inform the continuing debate on the trilogy's generic classification. 
This article subsequently begins with a brief recapitulation of Sassoon's war and the development of his poetics of commemoration. I posit that this poetics evolved in response to the forming and breaking of kinship bonds uniting Britain's fighting men on the Continent against the non-combatants they held responsible for their traumatic experiences. These kinship ties and the analgesic war narrative they produced then informed the three key elements of Sassoon's commemorative war-poetry: the attempt to maintain what Paul Arthur has termed "continuing bonds" with the deceased, an assertion of the necessity of first-hand battle experience informing any would-be war testimony, and the importance of individuals memorialising individuals $(2014,153)$. I next turn to consider the historical and narrative composition of the Sherston Trilogy. As I show in section II, war's end physically removed soldiers from one another and from the dangers that they believed would reunite them with their deceased comrades. This abrupt break compelled Sassoon to shift his course, after a long silence, away from an emphasis on 'ephemeral' works seeking to temporarily sustain kinship bonds with the deceased, and towards a more permanent form of commemoration capable of rescuing the larger relationship from obliteration.

Meanwhile, if nothing could fully deprive a soldier of his memories of service, neither could anything prevent their fading with time. As Sassoon notes towards the end of $I O$, accounts of discrete action in wartime may "look straightforward enough in print, twelve years later; but their reality remains hidden; even in the minds of old soldiers the harsh horror mellows and recedes" (457). Attempting to craft an account of his experiences on the Continent without the aid of his soldier-kin and separated from those experiences by an ever-expanding temporal gap, section III investigates Sassoon's heavy reliance upon his war-poetry and especially his front-line diaries to fill the growing lacunae in his memory while crafting Sherston's account. He incorporated thereby pieces of his own personality that he had sought to excise from the character of Sherston. This slow forgetting also uncovers larger problems in the very genre of memoir and its inability to relate a full and impartial account of one's experience. As I ask in the article's final section, how can a selectively constructed, post-facto narrative make any valid claim to impart objective truth? This impasse undermines the authority often assumed by the genre of memoir and troubles Sassoon-as-protest-poet's former insistence upon combatants' sole right to testify to the lived experience of war. Rather than resolve these issues in the Sherston volumes, Sassoon-as-memoirist now preferred to capitalise upon them, and to subvert the memoir's traditional assumption of textual authority into a successful play for narrative authenticity.

In shifting their focus from sustaining continuing bonds with the deceased towards permanent memorialisation, by borrowing heavily from his wartime writings, and now relinquishing their genre's implicit claim to portray the complete truth of their author's experiences, the Complete Memoirs represent a radical development in Sassoon's commemorative war-writing. As critics continue to negotiate Sassoon's position on the Great War bookshelf, this article asserts that the figure of Sherston can neither be subsumed completely into the personality 
of his creator nor completely divorced from him. Just as the fledgling memoirist in 1928 was not the same Sassoon who had imagined that he had "said [his] say" on the war when he collected his poems into a single volume in 1919, George Sherston is demonstrably more than a simulacrum of the poet Sassoon, but never wholly independent from his soldier-creator (Siegfried's Journey 1983, 167).

\section{Sassoon's Shifting Poetics of Commemoration}

But how did the younger Sassoon come to believe that he had crafted a complete poetic account of his experiences serving on the Continent? To see this, we must briefly recount Sassoon's war and the growth his poetics underwent after 1915. In some ways, Sassoon's traumatic sufferings were not so singular as one might expect, given his poetry's insistence on frontline experience as prerequisite for writing about the war. For example, he subscribes to a trend that Jay Winter has noted on the war's international homefronts. Winter has shown how the great stress occasioned by total war and its accompanying losses necessitated the coming-together of former strangers to help each other survive its devastation. These stresses created artificial families of "fictive kin", non-combatants found in "every combatant country" who "help[ed] each other recover from [the war's] traumatic consequences" (2000, 47). While homefront kinship groups initially formed to ensure that their members physically survived the war, however, Winter's primary interest is in the strategies these groups then developed to psychologically withstand its ravages. Chief amongst these was their shared attempts at working through the grief and trauma accompanying their experiences of hardship and loss. They did so, Winter concludes, on a small scale, repeated across thousands of independent locales, by crafting shared narratives of their war that accorded with their common and limited experiences (40-43).

Adapting Winter's argument to my reading of combatant-writers like Sassoon, I contend that soldiers formed their own kinship communities, continually developing overlapping war narratives and shared commemorative strategies before 1919. Unlike Winter's civilians the world over, however, British soldiers were exiled together in their millions along a narrow strip of France and Flanders. They were also largely young and universally male. These soldier-kin subsequently shared an experience of war that was much more homogeneous than those recounted by Winter's diverse civilian groups could ever hope to be. Soldier-writers' kinship-inflected narratives soon found expression in the frontline poetry that Sassoon and his poet-friends composed according to a nascent poetics of commemoration. When it reached maturity, this poetics finally comprised three interrelated components directly arising from its foundation in front-line kinship bonds:

1. The poet's/speaker's attempt to maintain "continuing bonds" with the deceased, 
2. An insistence upon the exclusivity of the combat experience that had effected those bonds (and a corresponding assertion of the soldier's monopoly on testimonial authority over other wartime populations), and,

3. The memorialisation of the individual by the individual.

This approach to commemorative writing first appears in Sassoon's poetry in 1916 . By the end of 1917 it had overtaken his page, ultimately producing the anti-pastoral and realist-satirical verse upon which his poetic reputation now rests. For poetry by Sassoon and others recording these bonds also formed the first canon of Great War-writing. Perhaps this should come as no surprise: powerful tributes to the fallen men to whom poet and speaker still felt themselves attached were as moving for readers in Britain as for soldier-kin. What is more, given their prioritisation of first-hand combat-experience, soldier-poets were able to complement these tributes with the heretofore unseen, realist depictions of trench-life for which the public was hungry. Finally, this poetry's insistence upon remembrance performed at or near the individual level represents the chief difference between First World War-writing and more conventional, collective forms of commemoration like the erection of physical monuments to the dead. This final tenet remains as compelling today as it ever has. While contemporary criticism has now articulated a case against the exclusionary narratives resulting from the insistence on first-hand experience (and the canons built in their aftermath), this process did not begin in earnest until the 1980s. The first dramatic change to the poetics of commemoration, then, naturally concerned the "continuing bonds" that former soldiers shared with the deceased and one another. This change was triggered by the end of hostilities on 11 November 1918, but in Sassoon's case took nearly two decades to find its full articulation in the Sherston Memoirs.

\section{2. "It is Ten Years Since": Delay:}

Sassoon's slow and often painful reformulation of his commemorative poetics was an inevitable consequence of the Armistice. When the guns fell silent in 1918, they ceased to threaten the lives of surviving soldier-kin at the same time as peace forced them apart from one another. The cessation of hostilities not only separated Sassoon from his living comrades, however: it also foreclosed the expectation and the hope of reunification that had accompanied him throughout the seemingly interminable conflict, and that had informed the original impetus for seeking to maintain his ties to the deceased. He could now no longer expect that he too would eventually, inevitably "go west" to re-join his lost kin. If Sassoon's wartime poetry and diaries attest to the anguish and guilt that the young lieutenant had felt when separated from his soldier-kin, he had expected all the while to re-join his comrades first in combat and ultimately in death. Peace instead halted the unfinished process of shared narrative construction that had 
brought relief from sustained traumatic experience: without the support of his soldier-kin, and feeling irremediably cut-off from his fallen comrades, Sassoon was unable for years to continue processing his war memories.

As one familiar with Cathy Caruth's newly augmented work on trauma and latency might expect, Sassoon now suffered a long period of artistic arrest (2016, 17-20). Wilson notes how, "determined to pursue his ambitions as a poet" in 1918, "with the passing of the war, he was left without a subject [... H]e could no longer mine that rich vein" (16). Where Wilson contends that this damming of his pen "contributed significantly to [Sassoon's] restlessness in the immediate post-war years", I argue instead that this "restlessness" proceeds from the same source as his writer's block: his permanent separation from his kin (16). A new experience of exile on the Homefront now prevented the collective refinement of his war narrative and rendered him incapable of committing it to paper. After all, how can one tell a history of his experiences that he has not yet finished piecing together? This stasis is likewise evident in the traumatic symptoms he continued to manifest years after war's end. Describing a nightmare Sassoon had in 1929, Max Egremont observes that he "had done 3,000 words of fair copying of what he called the 'Autobiography of an Infantry Officer' [...] One night he woke in tears after a horrifying war dream in which [his then-lover] Stephen [Tennant] had been condemned to death in the trenches" $(2006,344)$. Sassoon therefore continued to wrestle with the repercussions of his war-trauma in the form of writer's block on the subject of war, and by involuntarily re-experiencing that trauma in the form of intrusive nightmares.

While certainly painful, this involuntary mental repetition of his traumatic experiences eventually allowed Sassoon to finally begin to resolve them via the decade-long process of crafting George Sherston and his own prose-account. Travelling this new road towards the construction of a restorative narrative now required Sassoon to change his approach to commemorative writing. As we have seen, any focus on the maintenance of continuing bonds for the short term was no longer a tenable end goal; Sassoon instead evolved a new desire to permanently commemorate his fallen friends, and a related wish to protect himself against the fallibility of his own memory. Rather than short poetic portraits that convey the bitterness of loss as a salve while keeping the relationship alive in anticipation of an approaching reunification, Sassoon gradually came to understand that peace demanded the creation of a lengthier narrative that conveyed (more of) the weight of the larger relationship that was now threatened with termination, and continually receding with the passing of years.

This difficult history surrounding the Sherston Memoirs' composition is preserved within their very pages. Towards the end of FHM, for example, Sherston reflects on the fading connections he and Sassoon share with their former kin: "It is ten years since I uttered an infantry word of command: and I am only one of a multitude of men in whose minds parade ground phraseology has become as obsolete and derelict as a rusty kettle in a ditch. So much so that it seems quite illuminating to mention the fact" (234). While its increasing temporal 
distance makes the language of command seem clunky (like "a rusty kettle"), it is nevertheless "illuminating" for Sassoon to have Sherston recount it because doing so serves to renew somewhat his similarly fading connection with these words. Sherston next laments that, while he may be able to recall individual words, his larger hope for reconnection is a futile one: as he reasons, although "banished to the backs of our minds, those automatic utterances can still be recalled; but who can restore Clitherland Camp and its counterparts all over the country? Most of them were constructed on waste land; and to waste land they have relapsed" (235). Just as a memoirist must build his narrative from words-those building blocks of memory not individually susceptible to temporal fading-to convey some account of his experiences, so too are words the only thing that Sassoon can accurately recall in his isolation. Without the aid of his kin, Sassoon-as-memoirist cannot proceed to the more demanding work of reconstructing "Clitherland Camp" in vivid detail via those words. Sassoon builds upon this theme in $I O$, where he laments that the slow march of time has "obliterated the laughter of the war. I cannot hear it in my head. How strange such laughter would sound, could I but recover it as it was on such an evening as I am describing, when we all knew that we'd got to do an attack that night" (339).

While these selections, taken alone, would seem to imply that Sassoon could make no headway in processing his war-trauma, the Complete Memoirs demonstrate his slow progress maturing through his unresolved memories by working towards a renewed narrative of war. For example, IO tells of Sassoon's first experience of night-terrors at "Slateford" [Craiglockhart] War Hospital in 1917, long before the dream of Tennant's execution that he had when composing the volume. Sassoon here recounts having existed in a confused state between waking and sleeping, where he would see the "[s] hapes of mutilated soldiers [who] came crawling across the floor; the floor seemed to be littered with fragments of mangled flesh. Faces glared upward; hands clutched at neck or belly; a livid grinning face with bristly moustache peered at me" (453). While this passage conveys the horror of his experience, so does the Craiglockhart-era poem "Sick Leave", where the "noiseless dead" "whisper" to the speaker's "heart", accusing him of having abandoned his comrades "[f]rom Ypres to Frise" (2002, 78). Lieutenant Sassoon's feelings of guilt were resolved in early 1918, however, when he left Craiglockhart and was reunited with his "Battalion in the mud" (78). Elected self-sacrifice is no longer available to Sassoon-as-memoirist. On IO's following page he continues recounting his dream:

...A young English private in battle equipment pulled himself painfully toward me and fumbled in his tunic for a letter; as he reached forward to give it to me his head lolled sideways and he collapsed; there was a hole in his jaw and the blood spread across his white face like ink spilt on blotting paper... (Sassoon's ellipses 454)

Where the previous dream-section conveys his horrific hallucinations, this second excerpt indicates Sassoon's feelings of powerlessness in his attempts to 
keep alive the victim's story: the mutilated private lacks an intact mouth and cannot speak his story to Sassoon/Sherston, while his weeping wounds threaten to cover over his written account in blood-ink. Meanwhile, the dreamer cannot even process the image, framing it for himself in uneasy ellipses that demonstrate his uncertainty of the reality of the experience.

Sassoon does not remain in this limbo throughout the course of the trilogy, however. As Robert Hemmings has argued, SP demonstrates how he was able to work through these involuntary re-experiences of trauma by capturing that trauma in narrative $(2008,43-46)$. Consider against the dream related above Sassoon's later account of his post-war dreams, whose source, he tells his reader, "obviously dates from" the period of the first dream, "the autumn of 1917, when I made the choice [to return to service] which seemed like a 'potential deathsentence"' (SP 555-56). In the first dream,

I was with my battalion in some slough of despond, from which it seemed there was no way back. We were all doomed to perish in the worst possible of all most hopeless "dud shows." [...] Measured in terms of unmitigated horror, this dream was, I think, quite good peace propaganda. But the queer thing about it was that while in the thick of my dream-despair, I sometimes thought "Anyhow I am adding a very complete piece of war experience to my collection." This dream did not recur after I had written my account of military service. [...In the second] I actually find myself "out there" (though the background is always in England-the Germans have usually invaded half Kent). And, as in the first dream, I am vaguely gratified at "adding to my war experience." (554-55)

Two interrelated phenomena are noteworthy here: Sassoon's assertion that these traumatic episodes are capable of leaving him with a(n otherwise unavailable) "very complete piece of war experience", and his observation that the first dream ceased to recur after he had incorporated it into his war narrative. If, as he attests, he had suffered such recurrent nightmares "[s]ince the war", then it was the repetition of his past traumatic experiences and the composition of the memoirs that together recreated the healing effects of the now-faded kinship bond and prevented the dream from recurring-but on a much slower timeline (554). More than fifteen years after living through the events in question, and eight years after the publication of FHM, Sassoon has now formulated a healing narrative about a late-war experience that had heretofore remained locked away from him. It is impossible to say whether the composition of his narrative and its translation into prose incited Sassoon's recovery, or whether the slow process of healing facilitated the creation of that narrative. As the trilogy's opening pages assert, these processes are inherently interrelated:

as I look up from my writing, these memories also seem like reflections in a glass, reflections which are becoming more and more easy to distinguish. Sitting here, alone with my slowly moving thoughts, I rediscover many little details, known only to myself, details otherwise dead and forgotten 
with all who shared that time; and I am inclined to loiter among them as long as possible. (FHM 11)

As I have demonstrated, repeated experience and the work of composition forced Sassoon/Sherston to "rediscover" the details of his war by reconstructing his history in it, even as his success in so doing prompted him to continue this therapeutic process. While I have repeatedly emphasised the lack of continued access to his soldier-kin that forced this introspection, we must also remember that Sassoon always had recourse to his earlier written accounts of his experiences. Let us now consider the ways in which the memoirs re-incorporate Sassoon's extant poetry and diaries into his evolving war narrative, as well as the limited extent to which he altered them to fit his narrative frame.

\section{3. “O World God Made!”: Reiteration}

Cut off from his soldier-kin and slowly forgetting the vividness of his experience fighting, Sassoon-as-memoirist relied upon his earlier writings to inform much of his own history as he set about actively reconstructing it. While these certainly included his war-poetry, his primary source material was the diaries that he had kept while on active service and that had already facilitated the composition of that poetry. As Rupert Hart-Davis writes,

close comparison of these books [the Memoirs] with his diaries shows that they are faithful records of his experiences, based on his contemporary descriptions, occasionally heightened but never distorted. As time went on he came to rely more and more on the diaries, and Part III of Sherston's Progress consists entirely of quotations from them. $(1983,9)$

Indeed, if this cross-referencing is historically true of all of Sassoon's warwritings save the diaries themselves (his oeuvre's ur-text), then the Complete Memoirs take the practice a step further even than the poetry. Where Sassoon necessarily distanced his memoirs' narrative from his kin as he worked through his war-trauma alone, the soldiers' original, shared narrative of war is nevertheless discernible within the trilogy because of his sustained dependence on the diaries during its composition. If I have just suggested some of the ways in which the memoirs differ from the canonical war-poetry, to most readers these differences must necessarily seem minor. Instead of radically recrafting his own history fighting on the Continent, the trilogy's changes to the contents of Sassoon's poetic testimony consist mostly of a shifting emphasis on certain details comprising that experience-especially his relationships with his soldier-kin. What, then, are we to make of the substantial overlap that remains between the memoirs and his earlier writings on the war?

The answer to this question also lies within the Complete Memoirs' compositional history. In the twenty-first century we have greater resources at our disposal than did "Sherston's" first readers in 1928, including the very fact of the 
narrative's fictionalisation: Sassoon had withheld his name from the first edition of FHM so that the early reader unfamiliar with his history must have perceived a literal Sherston and taken him at his word (Hart-Davis 10). What is more, the posthumous publication of the Diaries (1983) has provided a key resource for deciphering the Complete Memoirs. Consider, for example, Sherston's attempts to downplay this dependence when he explains to the reader towards the end of FHM that he has relied on them only as a means for recalling historical facts: to "revert to my earlier fact, 'got to Béthune by half-past ten', it may well be asked how I can state the time of arrival so confidently", he begins: "My authority is the diary which I began to keep when I left England. Yes; I kept a diary, and intend to quote from it (though the material which it contains is meagre). But need this be amplified?..." (Sassoon's ellipsis 247-48). Here, Sassoon uses his diary to lend historical "authority" to his account of soldiering in France, but without acknowledging the subjectivity of his position as author of both texts, and without actually disclosing the true extent to which he has depended upon the diaries' "meagre" information throughout the composition process. This discrepancy alone is sufficient evidence to refute Hart-Davis' assertion that Sassoon "never distorted" his war accounts.

That said, the story told in the Complete Memoirs does not differ from the poetry of the late-war as much as one might expect, given the rapidity and volatility of his poetic development in wartime, or indeed as much as their author might have wished. Rather, because large parts of the text were extracted directly from Sassoon's diaries, they necessarily include information that he had sought to leave out of Sherston's account. Following the Diaries' publication, scholarship on Sassoon has made some progress uncovering exactly what these two iterations of his war narrative have in common. Egremont, for example, echoes Hart-Davis' when observing that $S P$ "abandons fresh composition and uses his diary entries", but continues to catalogue their differences (401). The Complete Memoirs, he contends, are:

slightly sanitized, with hints of sexual interest usually removed except "Howitt" asleep "with his moody sensual face and large limbs;" the entries about the soldier Linthwaite, to whom Sassoon had also been attracted, leave out anything too suggestive. [... Wilfred] Owen is left out completely. There is no poetry, and a rare glimpse of serious contemporary writing comes when Sherston reads Barbusse at "Slateford" and Duhamel in France. (401-02)

This is more accurate, but still in need of further qualification. Yet more precise would be to argue that Sassoon sought to excise his poetic self from his text and met with only limited success. If he managed to completely cut Owen from the text, for example, it cannot be said that the Sherston volumes contain "no poetry". While I take Egremont's assertion to mean 'there is no evidence qualifying Sherston as poet' instead of 'he steadfastly ignores poetry', Sherston's constant engagement with English poetry throughout each volume demonstrates 
that he has a poet's interest in poetry. This begins with FHM's very epigraph ("This happy breed of men, this little world"), taken from Richard II, which is noteworthy among Shakespeare's works for having been composed entirely in verse (7).

Similarly, while critics consistently highlight how non-bookish the persona of Sherston is-to Egremont, "Sherston is no literary man; books are bought mostly for their aesthetic appearance and almost his only mention of contemporary writing is a reference to Edmund Gosse's autobiography, Father and Son" - this reading is likely a result of Sherston's own repeated claims to literary ignorance (334). I would submit that the trilogy is sufficiently allusive to qualify the character as being well-read indeed. Consider the following (likely incomplete) table of Sherston's literary references: page numbers in bold indicate a reference to a work of poetry, and italicised numbers indicate writing published after 1910 (i.e., "contemporary"):

Table 1 Literary References throughout Sassoon, The Complete Memoirs of George Sherston

\begin{tabular}{|l|l|l|}
\hline Author & Reference & Notes \\
\hline Austen, Jane & 578 & \\
\hline Barbusse, Henri & 525 & \\
\hline Brooke, Rupert & $\mathbf{5 6 0}$ & \\
\hline Bunyan, John & 386,515 & \\
\hline Butler, Samuel & $\mathbf{3 8 4}$ & \\
\hline Byron, Lord George & 210 & $\begin{array}{l}\text { Reference is to the historical } \\
\text { person }\end{array}$ \\
\hline Carroll, Lewis & 567 & \\
\hline Conrad, Joseph & 590 & \\
\hline Cowper, William & $\mathbf{5 0 1 , 5 1 3}$ & \\
\hline de la Mare, Walter & $\mathbf{6 2 1 , 6 2 6}$ & \\
\hline Defoe, Daniel & 385 & \\
\hline Dickens, Charles & 350,606 & $\begin{array}{l}\text { References are to the historical } \\
\text { person }\end{array}$ \\
\hline Duhamel, Georges & $617,619,626$ & \\
\hline Flecker, James Elroy & $\mathbf{6 3 0 , 6 4 4}$ & \\
\hline Goldsmith, Oliver & 578 & \\
\hline Gosse, Edmund & 143 & \\
\hline Gray, Thomas & $\mathbf{4 9 4}$ & \\
\hline Haggard, H. Rider & 536 & \\
\hline & $\mathbf{2 1 8 - 1 9 , 2 8 7 , 3 2 5 ,}$ & \\
\hline Hardy, Thomas & $\mathbf{3 2 6 , 3 5 7 , 6 0 1 ,}$ & \\
\hline Homer & $\mathbf{6 2 0}$ & \\
\hline Johnson, Samuel & 80 & \\
\hline Keats, John & $400, \mathbf{5 0 7}$ & \\
\hline & & \\
\hline
\end{tabular}




\begin{tabular}{|l|l|l|}
\hline Khayyam, Omar & $\mathbf{3 9 9}, \mathbf{4 0 1}$ & \\
\hline Kropotkin, Peter & $478-79$ & \\
\hline Lamb, Charles & $287,452,619,625$ & \\
\hline $\begin{array}{l}\text { Longfellow, Henry Wad- } \\
\text { sworth }\end{array}$ & $\mathbf{2 2 , 1 5 3}$ & \\
\hline Milton, John & $\mathbf{3 8 4 , 4 0 0}$ & $\begin{array}{l}\text { 400: Reference is to the } \\
\text { historical person }\end{array}$ \\
\hline Molesworth, Mary Louisa & 22 & \\
\hline Palgrave, Francis Turner & $\mathbf{5 0 6}$ & \\
\hline Pater, Walter & 586 & \\
\hline Pope, Alexander & $\mathbf{8 0}$ & \\
\hline Rousseau, Jean Jacques & 501 & \\
\hline Sassoon, Siegfried & $\mathbf{5 3 9 , 6 1 3}$ & \\
\hline Scott, Walter & 22,592 & References are to the historical \\
\hline Service, Robert & $\mathbf{5 8 6}$ & historical person \\
\hline Shakespeare, William & $\mathbf{7 , 5 3 6 , 5 8 4}$ & \\
\hline Skelton, John & $\mathbf{3 8 4}$ & \\
\hline Smollett, Tobias & 80,578 & \\
\hline Stevenson, Robert Louis & 548 & \\
\hline Surtees, Robert Smith & $18,27,29,92$, \\
\hline Swift, Jonathan & 578 & \\
\hline $\begin{array}{l}\text { Swinburne, Charles Alger- } \\
\text { non }\end{array}$ & $\mathbf{6 2 8}$ & \\
\hline Tagore, Rabindranath & 464 & \\
\hline Tennyson, Lord Alfred & $\mathbf{9 2 , 5 4 5 - 4 6 , 5 5 3}$ & \\
\hline Tolstoy, Leo & $474,592,597$, \\
\hline Trollope, Anthony & $\mathbf{6 0 4 , 6 0 7 - 0 8 , 6 2 8}$ & \\
\hline Vaughan, Henry & $\mathbf{1 6 1}, 487-88$ & $\mathbf{6 2 8}$ \\
\hline Whitman, Walt & $\mathbf{4 8 8}$ & \\
\hline Wordsworth, William & & \\
\hline & & \\
\hline
\end{tabular}

While many of the trilogy's earliest references can be accounted for in Egremont's observation about young Sherston collecting "aesthetic[ally]" pleasing volumes, this ceases to be the case as Sherston matures into his library and then brings his favourite volumes with him on active service. The critical consensus on Sherston's non-literariness has not accounted for IO's relating a discussion about the relative merits of seventeenth-century English poets that Sassoon had with Graves (pseudonym David Cromlech) (384). It has also yet to reconcile SP's mapping of Sassoon's reading material so thoroughly that it might also serve as his reading journal for 1918, and has not addressed Sherston's late admission to having consulted "celebrated novelist[s]" during the composition process (519). 
No matter how much Sassoon had intended for his memoirs "to depend solely on [his] experiences as a sportsman", therefore, in having so consistently relied upon his own diaries and poetry as source material for their composition he could not excise his own bookishness from the character of Sherston (FHM 21).

Moreover, if Sherston is not a poet himself, he is nevertheless textually linked with Sassoon's own poetry of the war. IO relates Sherston's memory of an experience that Sassoon had earlier recreated in the poem "Arms and the Man". Instead of "Young Croesus" (2002, 25), it is now Sherston who espies

a neatly-framed notice [...that] stated the scale of prices for artificial limbs, with instructions as to how officers could obtain them free of cost. The room contained no other ornament. While I was adjusting my mind to what a journalist might have called "the grim humour" of this footnote to Army life, a Girl Guide stepped in to say that Colonel Crossbones (or whatever his cognomen was) would see me now. (IO 379)

If there is "no poetry" about Sherston, he still encounters scenes that would inspire a satirist like the younger Sassoon and makes similarly ironic observations and appellations ("Colonel Crossbones"). This is also to say nothing of his frequently being arrested by the beauty of nature, or the "literally hundreds of references to birds" that Patrick Campbell has noted in Sassoon's prose worksboth qualities found throughout poetry from every period of his life $(1999,168)$.

Despite these observations, however, there is yet more evidence of Sherston's poetic side: perhaps the most surprising entry amongst the authors named in the above table is Sassoon himself, for he could not prevent Sherston from directly quoting his own war-poetry. Recounting his 1918 return to France in SP, Sherston comments (once more like a poet!) on the uncanny contrast between the bucolic scenery before him and the flash and rumble of artillery meeting him from the horizon. "O world God made!", he remarks to himself (613), directly quoting the final line of The Old Huntsman's "At Carnoy", which draws a similar parallel between the sylvan and the martial $(2002,20)$. Of course, the diaries record Sassoon as having himself uttered this phrase in May, 1918; readers are left to wonder whether he did not notice the poetic artefact in the journal entry or he simply could not resist including it in Sherston's account $(1983,249)$. In either case, by relying so heavily upon his own diaries to recreate his war experiences, Sassoon incorporated significant elements of his own war-poet persona into the character of Sherston. The text subsequently also retains key components of the soldiers' narrative of war that Sassoon had built in close communication with his soldier-kin during his years of service.

In section II I contended that the changes that the Memoirs made to earlier iterations of Sassoon's war testimony demonstrate his post-Armistice workingthrough of traumatic experience independent of his warrior-kin. But separation also threatened to dull the vivid memories that Sassoon had shared with his comrades: the large overlap that Sherston's narrative shares with that of Sassoon's former kinship group is subsequently also a result (often despite his efforts to 
suppress certain elements of his own personality) of the memoirist's continued dependence upon his diaries during composition, and the kinship-inflected narrative contained within those diaries' pages. The content of the Memoirs was therefore directly influenced by the Armistice having separated Sassoon from his living lifeline, his kinship group; it also betrays the extent of his earlier dependence upon this human resource for formulating his own narrative before 1919. Let us now turn and consider what impact his deceased brothers in arms had upon his writing.

\section{Life-Writing, “Truth”, and Sassoon's Memoirs:}

I have already observed that the Sherston Trilogy was initially read as a true account of war because of its dependence upon Sassoon's diaries, as well as its prioritisation of his first-hand combat experience. After all, its longform title attests that these Complete Memoirs are the full, official testimony of Sassoon's alter-ego George Sherston. That said, although Sassoon's project was almost immediately incorporated into the larger British narrative of the war, a close reading of Sassoon's interactions with its source materials betrays the precariousness of any memoir's claims to testimonial authority. This is precisely because neither written accounts nor remembered experiences can support a claim to historical objectivity. Instead of attempting to resolve this paradox, Sassoon prefers to alternately highlight and critique both of his sources' claims to authority throughout the trilogy: while the text at times gestures towards historical objectivity, it just as often undermines its own claims to truth. Sassoon therefore preferred to relinquish his memoirs' claims to authority in a bid for narrative authenticity: that is, he forged an account that he perceived as true in spirit to the events that it relates by conceding that it is ineligible for any claim to objectivity regarding its depiction of those events.

For simplicity's sake, in this article I have employed Sassoon's own terminology of "authority" and "authenticity". Paul Jay has used a corresponding pair of terms while discussing Michel Foucault's reading of Friedrich Nietzsche's historiography_ "traditional history" and "artistic history" - and his observations are relevant here $(1984,112)$. If, as Jay suggests, all autobiography is a kind of "historical narrative per se", then it shares history's own problems in conveying a complete truth (108). He continues to emphasise Nietzsche's argument that it is "the historian's task to be artistic and creative rather than 'scientific', or 'objective"' (Jay's emphasis 109). Foucault's/Jay's "traditional history" thus corresponds with Sassoon's "authority", in that each represents an unattainable, complete, and ideal truth; "artistic history" pairs similarly with Sassoon's "authenticity" by crafting a partial narrative that is true to the spirit of one's memories. The root difference between authority and authenticity in Sherston's Memoirs subsequently lies in Sassoon's considered deployment of his two distinct sources, each with different-but ultimately imperfect—claims to objectivity. The resulting generic tension has prevented critics after Bergonzi from following Sassoon's first readers and accepting the Memoirs as an unvarnished account of "Sherston's" 
war experience for two reasons. First, its deliberate use of the diaries to inform the author's own fading memories means that the text's experiential foundation cannot support its occasional claims to testimonial authority, whatever Sherston's gestures towards (or away from) the reliability of his account. Second, Sassoon felt it necessary to make numerous changes to Sherston's war-story in addition to those enumerated in section II above, deliberately opening his narrative to the possibility that others' experiences might claim their own right to testimonial authenticity. Rather than account for this radical philosophical departure from his earlier approach to war-writing, Sassoon simply has Sherston admit to having done so. There is no mention of the consequences that this decision might have for Sassoon's earlier poetry and its insistence on the writer's first-hand experience of combat. Together, these factors explain the difficulty that critics have had in agreeing upon an appropriate generic designation for the trilogy.

Discussing testimonial novels, Brian Artese explains that testimony's relationship to truth is more complicated than someone like Sherston might seem to admit: "the claims of causality and the narrative-driven demarcation of events in any historiography, which allow a mere chronicle to be knit into historical narrative, are acts of judicious interpretation. No historian would suggest such [a] narrative could achieve the status of unquestionable Truth" (2012, 25). As each entry within Sassoon's war-oeuvre demonstrates, the selective process of fashioning a 'history' invariably invalidates any claim that account might make to narrative objectivity, no matter the seeming-imperviousness of its sources. This is especially true of accounts attached to a name. A "report bound to a signature or name", contends Artese, "will, for that reason alone, contribute more to the memoir than to the history, more to the literary than to the real" (17). This relationship applies to 'historical' narratives like life-writing in all its guises. Where Artese warns novel readers to remain wary on the grounds that "the interpretive and evaluative operation of any historiography can be screened from view simply by making reference to its traffic in value-free facts", one must be doubly vigilant with respect to the Sherston Trilogy and its repeated assertions to the facticity of Sherston's/Sassoon's diaries, from which its own ostensible authority would draw its strength (54). We have already departed from Sherston's first readers, then, because we cannot approach the Memoirs as objective, historical accounts of his war experiences. Even if Sherston occasionally champions the authority of his war-diaries, using them in tandem with his own memories to spin the narrative thread of his memoirs, we must counter that neither diary nor memory can truly claim to be authoritative. The diaries' immediacy to the events related only imbues them with an air of authority - that is, with authenticity.

Having made a claim to his text's authority that its sources cannot support, Sassoon-as-memoirist next recreates a second phenomenon noted by Artese. As he explains, staging an act of revelation will, however paradoxically, allow a text to again assume an aura of authority: "If a drawn veil always exposes a once-hidden truth, even a purely staged motion of unveiling-a journalistic performance of 'eyewitness penetration' into the heart of darkness-will seem 
to guarantee the advent of truth" (13). It is this act of unveiling that Sassoon depends upon throughout the Complete Memoirs-hence Sherston's repeated assertions grounding the narrative in his own diaries. While neither diary nor memory can actually produce complete accounts of lived experience, the diaries' extended detail and temporal proximity to the events related means that they come closer to telling Sassoon's whole story than his reconstructed memories could do unaided. By having Sherston repeatedly emphasise that his memories are complemented by his own contemporary written accounts, Sassoon depends upon the unreliability of the former source to obscure the unreliability of the latter. In short, because memory is more imperfect than a contemporary written record, Sherston's repeated assertions that the diaries inform his account serve to draw the reader's attention away from a more careful consideration of the diaries' own problematic claims to narrative authority. By revealing the flaws inherent to re-creation through recollection, therefore, Sassoon has Sherston 'draw the veil' for his reader, staging an act of revelation whose actual effect is to downplay the text's greatest weakness regarding any claim to authorial truth.

This is a delicate enough manoeuvre and not uncommon amongst autobiographical accounts by Great War-writers and others. Sassoon, however, proceeds a step further towards sacrificing testimonial authority in a bid for narrative authenticity: he once more 'draws the veil' for his reader, this time upon the staged revelation I have just related. While I have already highlighted Sherston's gestures suggesting the reliability of the diaries, he also repeatedly confesses the problems inherent to their claims to authority. In place of consistently asserting the power of his own memories' foundation in lived experience and attempting to raise them to the assumed authority of the diaries, then, Sherston highlights the fallibility of the diaries to bring them down almost to the level of his more-imperfect, reconstructed memories. Whatever his occasional overtures towards the diaries' testimonial authority, then, by highlighting the fallibility of both The Complete Memoirs' real-life sources, as well as his own trick in obscuring that fallibility - by twice drawing the veil on his narration's sleights of hand-he transfigures those sources' (impossible) claims to authority into a staged revelation investing the account with authenticity. We see this early on, in FHM, when Sherston confesses that, even if we accept their historical facticity, he must regret the diaries' paucity of detail: "how much is taken for granted and left unrecorded in that shorthand description? And how helpful it would have been now if I had written an accurately observed and detailed narrative of the day. But since the object of these pages is to supply that deficiency I must make my reminiscent deductions as best I can" (146-47). Sherston therefore admits that what he is doing is an exercise in "deduction[]" rather than objective recounting. He similarly emphasises the gaps in his memory that undermine the authority of his account. We have already seen him attest to his faith in his ability to remember individual words, but not entire episodes. This is especially true when the requisite memories rely on his senses for their vividness; against something as rich as a remembered sensation, 
Sherston's memory fails him repeatedly. As he laments, he cannot remember so much as a cup of tea: "If I could taste that tea out of the dixies now I should write it all very much as it was. Living spontaneity would be revived by that tea, the taste of which cannot be recovered by any effort of memory" (252). Rather than attempt to imbue his memory with an authority it cannot claim, Sherston instead highlights the weakness that his written source shares with his fading recollection. This has the effect of drawing the reader further into a narrative of his experience that still provides otherwise-inaccessible truths, and that, while unable to convey an impossible truth, nevertheless reads as truthful.

Instead of attempting to reconcile the discrepancies between his own account and its genre's assumed claim to textual authority, then, Sherston simply warns his readers that "those who expect a universalization of the Great War must look for it elsewhere", while making a case for the British reading public to reorient their own ideas about the war by extrapolating from his testimony (291). Sassoon was therefore aware of the problems inherent to any text positioning itself as an objective account of lived experience. Given the larger commemorative goals of the Sherston Trilogy, this sacrifice of narrative authority for authenticity is a pragmatic move by an author faced with a problem that has yet to be resolved by any memoirist. Specifically discussing this problem within autobiographical writing, Paul Jay quotes James Olney in asserting that "there are no rules or formal requirements binding the prospective autobiographerno restraints, no necessary models, no obligatory observances gradually shaped out of a long developing tradition"' (15), before denying that autobiography represents a discrete genre on these grounds (16-17). He then proceeds to read this problem into the language's best-known autobiographical texts that together produce "an emerging realization that autobiographical (and historical) practice is fraught with serious paradoxes" (118). As I have argued, Sassoon's primary interest in writing Sherston's war was not in resolving the paradoxes inherent to autobiographical writing, but in creating a permanent means of commemorating his fallen soldier-kin, and of constructing a permanent record of the war whose underlying experiences they had shared.

While the Memoirs ultimately relinquish their own claim to historical truth, they can convincingly position themselves as being true in spirit to Sassoon's war experience. Hence his readiness to apply the label "memoir" to these partially fictionalised works versus Jay's hesitance to acknowledge that autobiography can exist non-problematically as a genre. While this explains The Complete Memoirs' enthusiastic critical reception, it also accounts for the history of their fraught generic classification: Sassoon's choice to sidestep one of the fundamental tensions of autobiographical life-writing ironically means that the trilogy qualifies as neither strictly autobiographical nor fictional-as a fictive construction authentically relating lived experience, The Sherston Trilogy must be classed as memoir, but with a conspicuous asterisk always following that designation. 


\section{Conclusion: The Evolution and Mythification of Sassoon's War Narrative}

As Peter Burke writes of memoirs at large, such "records are not innocent acts of memory, but rather attempts to persuade, to shape the memory of others [...W] e do not read memory itself but its transformation through writing" $(2011,189)$. My exercise throughout this article has been to apply this assertion to the Complete Memoirs of George Sherston, which has long been read alternately as an unvarnished account of Sassoon's war or as a fiction loosely grounded in that experience. While the text can at times encourage either reading, accepting Sherston's claims to authorial veracity at face value would mean ignoring fundamental components of the trilogy's composition (including his admissions to the contrary). Classing it as fiction meanwhile downplays its significant reliance upon Sassoon's own lived experience and his wartime writings. Sassoon's realisation that experiential narratives can attain authenticity but not perfect authority explains his success at fictionalisation, while this fictionalisation's significant implications for the text as would-be memoir account for critics' difficulty in categorising these works generically. As I have shown, these seemingly irreconcilable components originate not with the memoirs' author but in their very genre, and in the collective but incomplete war narrative that Sassoon had refined with his fellow soldiers until the Armistice forced their separation in November 1918.

I have also shown how separation from his former kin long prevented Sassoon from continuing the healing process of refining his experiential narrative, and accounts for his reliance upon his diaries during composition. That Sassoon was not granted the soldier's death he had long expected similarly forced him to shift his commemorative focus away from maintaining short-term "continuing bonds" with his deceased comrades. He instead sought to create a permanent textual record of his service that would preserve the experiences informing those bonds. This shift explains Sassoon's decision to compose lengthy prose memoirs in place of short verse-memorials. Meanwhile, his repeated dependence upon his extant war-poetry and especially his trench-diaries means that Sherston is not quite the unpoetic and de-sexualised simulacrum of his author-creator that that creator had intended him to be.

This new investigation of a canonical text has also suggested how the success of the Memoirs allowed them to so disproportionately inform the collective British memory of the Great War. Their overrepresentation must now be accounted for and countered with a continued expansion of the Great War library beyond the works of combatant-writers. As Samuel Hynes has explained, the call to reevaluate the canon - and to re-read its central texts-is one well worth repeating: what Hynes calls the "Myth of the War"

was given its fullest definition in the years around the end of Twenties, when the great war memoirs and novels, and the first full edition of the poems of Wilfred Owen, were published. No generation since then has 
questioned its validity, and it remains the accepted interpretation of the war, repeated in texts written by authors who did not experience the war, but who inherited its myth. $(1992, \mathrm{x})$

Hynes' Myth, diagnosed half a century after the Complete Memoirs' conclusion, represents the war narrative adopted by the British public in the decades following the Armistice. Given Sassoon's inability to fully separate the figure of Sherston from himself, it should probably not surprise us that the combatants' war narrative that had informed his poetry is incorporated largely unaltered into most readings of Sherston's Memoirs. Nor should it surprise us that those memoirs came to constitute a significant component of Britain's national Myth, even if they quietly relinquish Sassoon's earlier insistence that the soldierwriter represents the only possible arbiter of truth in war. Thirty years after Hynes' book, I now contend that Sassoon-as-memoirist sought to solidify and expand upon the testimonial project begun in the war-poetry, and that his exchange of authority for authenticity was rather too successful.

Too successful because Sassoon's war narrative was to change course once more, this time in response to his civilian's experiences throughout the Second World War. His trilogy of 'conventional' autobiographies-The Old Century and Seven More Years (1938), The Weald of Youth (1940), and Siegfried's Journey, 1916-1920 (1945)-represents the final iteration of Sassoon's Great War testimony, his last attempt at creating a still-more-authentic account of his Great War experiences from a renewed perspective. He included thereby much that had been omitted from Sherston's history, in addition to the civilian's experience of total war he acquired while writing. While they lend further insight into our understanding of his first war, however, they were not incorporated into Hynes' Myth: amongst the competing Sassoons that comprise the figure dominating the Great War canon-Sassoon-as-soldier, Sassoon-as-diarist, Sassoon-as-protestpoet, Sassoon-as-memoirist, Sassoon-as-Sherston-the warrior-poet Sassoon and the genteel-sportsman Sherston are almost invariably the figures that Britons read and reference. This, despite their incongruities to Sassoon's lived experience, to his later publications, and to each other.

\section{Works Cited}

Artese, Brian. Testimony on Trial: Conrad, James, and the Contest for Modernism. University of Toronto Press, 2012.

Arthur, Paul. "Memory and Commemoration in the Digital Present." Contemporary Approaches in Literary Trauma Theory, edited by Michelle Balaev, Palgrave Macmillan, 2014, pp. 152-75.

Bergonzi, Bernard. Heroes' Twilight: A Study of the Literature of the Great War. Carcanet, 1996.

Burke, Peter. "From 'History as Social Memory." The Collective Memory Reader, edited by Jeffrey K. Olick et al., Oxford UP, 2011, pp. 188-92.

Campbell, Patrick. Siegfried Sassoon, A Study of the War Poetry. MacFarland and Company, 1999. 
Caruth, Cathy. Unclaimed Experience: Trauma, Narrative, and History. Johns Hopkings UP, 2016.

Das, Santanu. India, Empire, and First World War Culture: Writings, Images, and Songs. Cambridge UP, 2018.

Edwards, Paul. "British War Memoirs." The Cambridge Companion to the Literature of the First World War, edited by Vincent Sherry, Cambridge UP, 2008, pp. 15-33.

Egremont, Max. Siegfried Sassoon: A Biography. Picador, 2006.

Fussell, Paul. The Great War and Modern Memory. Oxford UP, 2000.

Hart-Davis, Rupert. "Introduction.” Diaries: 1915-1918, by Siegfried Sassoon, edited by Hart-Davis, Faber and Faber, 1983, pp. 9-11.

Hemmings, Robert. Modern Nostalgia: Siegfried Sassoon, Trauma and the Second World War. Edinburgh UP, 2008.

Hynes, Samuel. A War Imagined: The First World War and English Culture. Pimlico, 1992.

Jay, Paul. Being in the Text: Self-Representation from Wordsworth to Roland Barthes. Cornell UP, 1984.

Minogue, Sally and Andrew Palmer. The Remembered Dead: Poetry, Memory and the First World War. Cambridge UP, 2018.

Sassoon, Siegfried. "Arms and the Man." The Old Huntsman and Other Poems. Collected poems, Faber and Faber, 2002, p. 25.

"At Carnoy." The Old Huntsman and Other Poems. Collected poems, Faber and Faber, 2002, p. 20.

Diaries 1915-1918, edited by Rupert Hard-Davis. Faber and Faber, 1983.

. Memoirs of a Fox-hunting Man. The Complete Memoirs of George Sherston, Faber and Faber, 1980, pp. 7-282.

. Memoirs of an Infantry Officer. The Complete Memoirs of George Sherston, Faber and Faber, 1980, pp. 283-514.

Sherston's Progress. The Complete Memoirs of George Sherston, Faber and Faber, 1980, pp. 515-656.

"Sick Leave." Counter-Attack and Other Poems. Collected poems, Faber and Faber, 2002, p. 78.

. Siegfried's Journey, 1916-1920. Faber and Faber, 1983.

. The Complete Memoirs of George Sherston. Faber and Faber, 1980.

. The Old Century and Seven More Years. 1938. Faber and Faber, 1986.

The War Poems. Faber and Faber, 1988.

The Weald of Youth. 1940. Faber and Faber, 1986.

Wilson, Jean Moorcroft. The Journey from the Trenches: A Biography 1918-1967. Routledge, 2005.

Winter, Jay. "Forms of kinship and remembrance in the aftermath of the Great War." War and Remembrance in the Twentieth Century, edited by Winter and Emmanuel Sivan, Cambridge UP, 2000, pp. 40-60.

Recebido em: 15/01/2021 Aceito em: 05/03/2021 